\title{
APLIKASI STATISTIK BOSE-EINSTEIN
}

\author{
Arini Rosa Sinensis ${ }^{1 *}$, Efrien Dian ${ }^{2}$, Thoha Firdaus ${ }^{3}$ \\ ${ }^{1,3}$ Program Studi pendidikan Fisika Stkip nurul huda \\ *Email: arini@ stkipnurulhuda.ac.id
}

Statistik Bose-Einstein Gditerapkan pada assembli boson, yaitu partikel kuantum dengan spin yang merupakan kelipatan bilangan bulat dari $\hbar$. Contoh boson adalah foton, fonon, dan atom helium. Berikut ini adalah aplikasi statistic Bose-Einstein

\section{RADIASI BENDA HITAM}

Radiasi elektromagnetik yang berada dalam suatu ruang tertutup bertemperatur tetap dapat dipertimbangkan sebagai suatu sistem foton-foton dengan berbagai nilai energi. Dan karena foton-foton memiliki momentum angular integral dalam satuan $h / 2 p$ maka mereka akan secara alami berkelakuan sebagai boson dan dapat diasumsikan bahwa suatu gas foton akan memiliki distribusi energi yang diberikan oleh statistik BoseEinstein. Akan tetapi, terdapat dua hal yang harus diperhatikan.

Pertama, foton dapat diserap dan dipancarkan kembali oleh dinding lingkungan tertutup yang bertemperatur tetap, dengan demikian jumlah foton dalam lingkungan tersebut tidaklah tetap. Dengan demikian kondisi

$$
\begin{aligned}
& \sum_{s} n_{s}=N \text { atau } \sum_{s} d n_{s}=0 \text { dalam } \\
& d \ln W+\alpha \sum_{s} d n_{s}+\beta \sum_{s} \epsilon_{s} d n_{s}=0
\end{aligned}
$$

tidak dapat terpenuhi.

Agar Persamaan 1) masih dapat berlaku maka perlu dipilih bahwa $\alpha=0$ sehingga $A=1$.

Kedua, energi foton berbentuk $h v$, di mana $v$ adalah frekuensi radiasi. Oleh karena itu lebih memudahkan apabila distribusi energi diungkapkan dalam frekuensi atau panjang gelombang foton. Dengan menggunakan rumusan panjang gelombang de Broglie:

$$
\begin{aligned}
\lambda=\frac{h}{p} \quad \rightarrow \quad p & =\frac{h}{\lambda}=h \lambda^{-1} \\
d p & =-\frac{h}{\lambda^{2}} d \lambda
\end{aligned}
$$

Dengan menggunakan elemen ruang fasa enam dimensi 


$$
d \Gamma=4 \pi V p^{2} d p=4 \pi V\left(\frac{h}{\lambda}\right)^{2}\left(\frac{-h}{\lambda^{2}} d \lambda\right)=-4 \pi V \frac{h^{3}}{\lambda^{4}} d \lambda
$$

Jumlah Keadaan energi dalam rentang $\lambda$ sampai $\lambda+\mathrm{d} \lambda$ tiap volume: (dengan mengambil nilai positif) :

$$
g(d \lambda)=\frac{d \Gamma}{h^{3}}=\frac{4 \pi}{\lambda^{4}} d \lambda
$$

Selanjutnya karena setiap foton memiliki kemungkinan polarisasi pada dua arah maka jumlah keadaan energi yang diperbolehkan atau mode, dalam rentang antara $\lambda$ dan $\lambda+$ $d \lambda$, untuk setiap satuan volume adalah

$$
g(\lambda) d \lambda=2 \frac{4 \pi}{\lambda^{4}} d \lambda=\frac{8 \pi}{\lambda^{4}} d \lambda
$$

Melalui distribusi Bose Einstein, dimana energinya $h v=(h c) / \lambda$ dan Persamaan sebelumnya A sama dengan 1. diperoleh:

$$
n_{s}=\frac{g_{s}}{e^{h v / k T}-1}=\frac{g_{s}}{e^{h c / k T}-1}
$$

Jumlah foton dalam rentang panjang gelombang antara $\lambda$ dan $\lambda+d \lambda$ adalah :

$$
n(\lambda) d \lambda=\frac{8 \pi}{\lambda^{4}} d \lambda \cdot \frac{1}{e^{h c / k T}-1}
$$

Dimana $c$ adalah kecepatan cahaya. Distribusi spektral dari energi pada gas foton dapat didefenisikan dalam bentuk $E(\lambda)$, energi radiasi dalam rentang panjang gelombang antara $\lambda$ dan $\lambda+d \lambda$ :

$$
E(\lambda) d \lambda=n(\lambda) h v
$$

Karena energi setiap foton $h v$.

Dengan mensubsitusikan nilai $n(\lambda) d \lambda$ dari Persamaan (4), diperoleh energi radiasi dalam rentang panjang gelombang antara $\lambda$ dan $\lambda+d \lambda$ adalah:

$$
E(\lambda) d \lambda=\frac{8 \pi h c}{\lambda^{5} e^{h c / \lambda k T}-1} d \lambda
$$

Ekspresi dalam persamaan (5) dikenal sebagai Hukum Radiasi Planck untuk distribusi spektral dari energi radiasi dalam suatu lingkungan tertutup bertemperatur konstan.

\section{Hukum Pergeseran Wien}

Ilustrasi distribusi energi spektral dapat dilihat dalam Gambar 1. Tampak bahwa $E(\lambda)$ mula-mula naik, kemudian turun setelah mencapai nilai maksimum pada panjang gelombang $\lambda_{m}$. Kita dapat menentukan $\lambda_{m}$ dengan mendeferensialkan $E(\lambda)$ terhadap $\lambda$ dan menyamakan $\lambda$ dengan $\lambda_{m}$, atau 


$$
\left.\frac{d E(\lambda)}{d \lambda}\right|_{\lambda m}=0
$$

Berdasarkan persamaan (5) maka

$$
E(\lambda)=\frac{8 \pi h c}{\lambda^{5} e^{h c / \lambda k T}-1}
$$

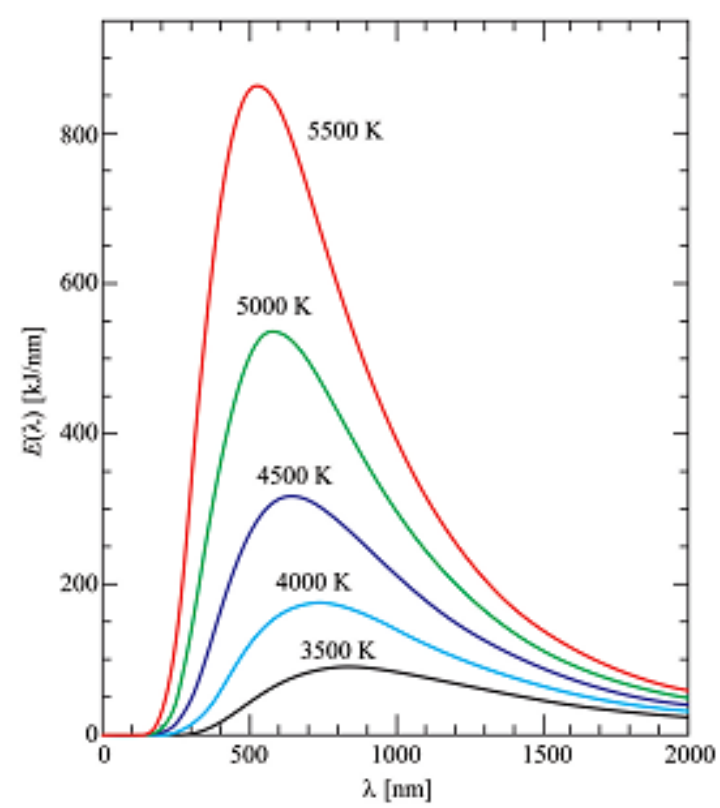

Gambar 1. Spektrum radiasi benda hitam pada berbagai suhu

Untuk memudahkan diferensiasi persamaan (7) persamaan di atas kita misalkan $x=\lambda k T / h c$. Dengan pemisalan maka kita dapat menulis

$$
\begin{aligned}
& E(\lambda)=8 \pi h c\left(\frac{k T}{h c}\right)^{5} \frac{1}{x^{5}\left(e^{1 / x}-1\right)} \\
& \frac{d E(\lambda)}{d \lambda}=\frac{d E(\lambda)}{d x} \frac{d x}{d \lambda}=\frac{k T}{h c} \frac{d E(\lambda)}{d x} \\
& =\left(\frac{k T}{h c}\right) 8 \pi h c\left(\frac{k T}{h c}\right)^{5} \frac{1}{x^{5}\left(e^{1 / x}-1\right)}
\end{aligned}
$$

Agar terpenuhi $d E / d \lambda=0$ maka pada persamaan (9) harus terpenuhi

$$
\frac{d}{d x}\left(\frac{1}{x^{5}\left(e^{1 / x}-1\right)}\right)=0
$$

Jika kalian lakukan diferensiasi secara seksama akan dapatkan hubungan berikut ini.

$$
(1-5 x) e^{1 / x}-5=0
$$


Nilai $x$ pada persamaan (11) dapat diselesaikan dengan berbagai cara. Jika kita menggunakan instruksi Mathematica (Wolfram Research), maka solusi untuk $x$ yang memenui persamaan (11) adalah 0,194197. Dengan demikian, $\lambda_{m}$ memenuhi hubungan

$$
\frac{\lambda_{m} k T}{h c}=0,194191
$$

atau

$$
\lambda_{m} T=0,194191 \frac{h c}{k}
$$

Dengan menggunakan nilai konstanta $k=1,38 \times 10^{-23} \mathrm{~J} / \mathrm{K}, h=6,625 \times 10^{-34} \mathrm{Js}$, dan $c=3 \times 10^{8} \mathrm{~m} / \mathrm{s}$, maka kita peroleh

$$
\lambda_{m} T=2,8 \times 10^{-3} m K
$$

Persamaan (12) tidak lain daripada ungkapan hukum pergeseran Wien. Hukum ini menjelaskan hubungan antara suhu benda dengan gelombang dengan intensitas maksimum yang dipancarkan benda tersebut. Makin tinggi suhu benda maka makin pendek gelombang yang dipancarkan benda tersebut, atau warna benda bergeser ke arah biru. Ketika pandai besi memanaskan logam maka warna logam berubah secara terus menesur dari semula merah, kuning, hijau dan selanjutnya ke biru-biruan. Ini akibat suhu benda yang semakin tinggi.

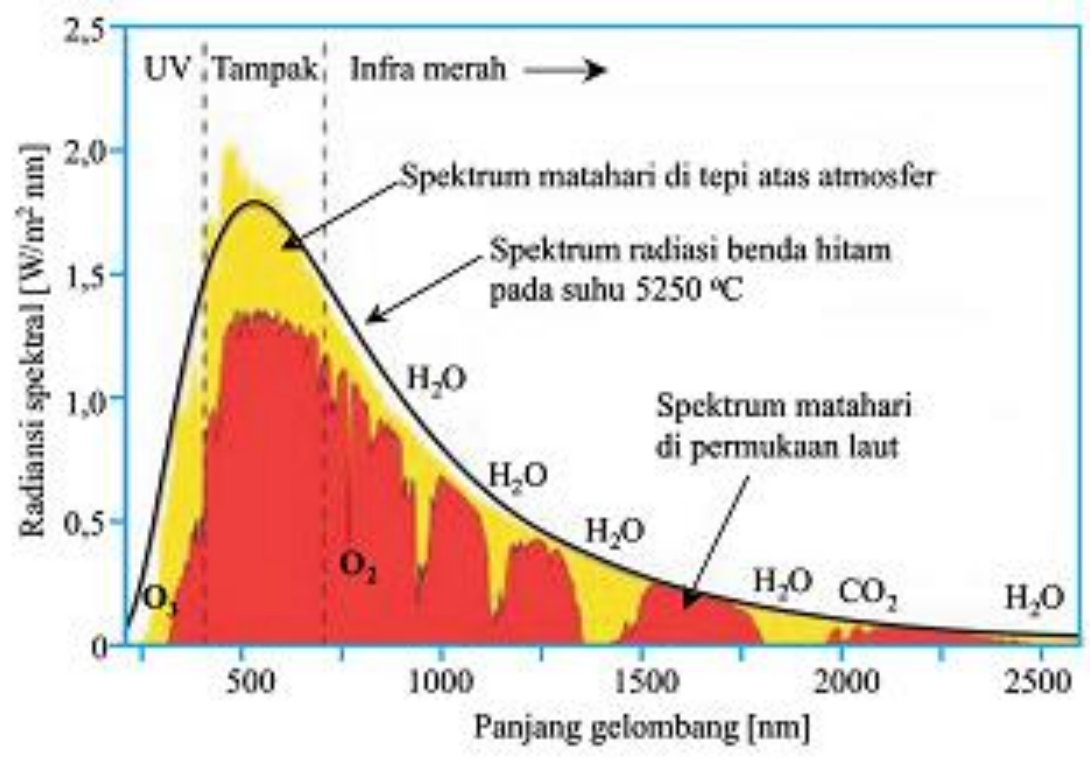

Gambar 2. Spektrum energi radiasi matahari berdasarkan hasil pengukurandan prediksi dengan persamaan radiasi benda hitam (garis).

Hukum pergeseran Wien telah dipakai untuk memperkirakan suhu benda berdasarkan spektrum elektromagnetik yang dipancarkannya. Energi yang dipancarkan benda diukur pada berbagai panjang gelombang. Kemudian intensitas tersebut diplot terhadap panjang gelombang sehingga diperoleh panjang gelombang yang memiliki intensitas 
terbesar. Panjang gelombang ini selanjutnya diterapkan pada hukum pergeseran Wien guna memprediksi suhu benda. Gambar 2 adalah pengamatan spektrum radiasi matahari di sisi atas atmosfer dan di permukaan laut. Kurva radiasi benda hitam juga dilukiskan. Tampak bahwa radiasi matahari cocok dengan kurva benda hitam yang memiliki suhu $5250^{\circ} \mathrm{C}$. Para astronom memperkirakan suhu bintang-bintang berdasarkan spektrum energi yang dipancarkan oleh bintang-bintang tersebut. Gambar 3 adalah contoh spektrum yang dipancarkan bintang-bintang yang memiliki warna yang berbeda-beda.

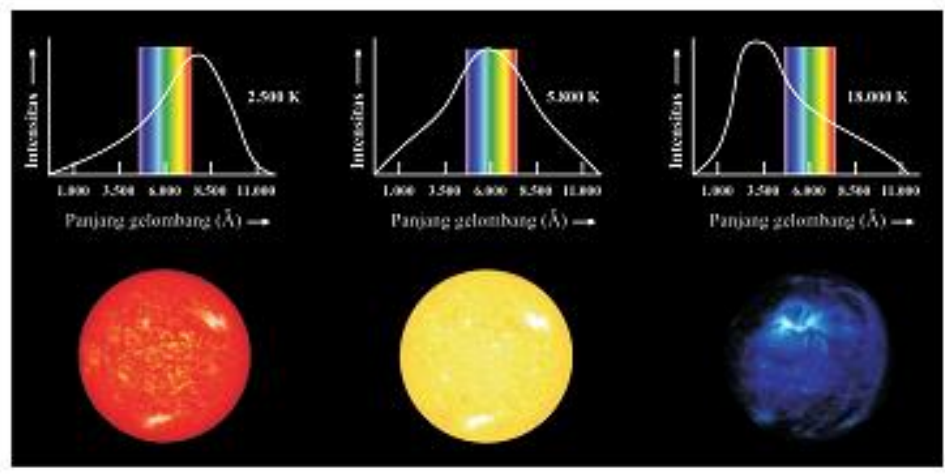

Gambar 3. Warna bintang menginformasikan suhu bintang. Makin menuju ke warna biru maka suhu bintang making tinggi. Sebaliknya makin menuju ke warna merah maka suhu bintang makin rendah

\section{Persamaan Stefan-Boltzmann}

Sebuah benda hitam memancarkan gelombang elektromagnetik pada semua jangkauan frekuensi dari nol sampai tak berhingga. Hanya intensitas gelombang yang dipancarkan berbeda-beda. Ketika panjang gelombang menuju nol, intensitas yang dipancarkan menuju nol. Juga ketika panjang gelombang menuju tak berhingga, intensitas yang dipancarkan juga menuju tak berhingga. Intensitas gelombang yang dipancarkan mencapai maksimum pada saat $\lambda=\lambda_{m}$. Sekarang kita akan menghitung energi total yang dipancarkan oleh benda hitam. Energi total tersebut diperoleh dengan mengintegralkan persamaan (5) dari panjang gelombang nol sampai tak berhingga, yaitu

$$
E=\int_{0}^{\infty} E(\lambda) d \lambda=8 \pi h c \int_{0}^{\infty} \frac{1}{\lambda^{5}} \frac{d \lambda}{e^{h c / \lambda k T}-1}
$$

Untuk menyelesaikan integral (13) mari kita misalkan $y=h c / \lambda k T$.

Dengan permisalan tersebut maka diperoleh ungkapan-ungkapan berikut ini 


$$
\begin{aligned}
& \frac{1}{\lambda}=\frac{k T}{h c} y \\
& \frac{1}{\lambda^{5}}=\left(\frac{k T}{h c}\right)^{5} y^{5} \\
& \lambda=\frac{h c}{k T} \frac{1}{y} \\
& d \lambda=-\frac{h c}{k T} \frac{1}{y^{2}} d y
\end{aligned}
$$

Sekarang kita tentukan syarat batas yang berlaku bagi y. Saat $\lambda=0$ maka $y=\infty$ dan saat $\lambda=\infty$ maka $y=0$. Dengan demikian, dalam variable y integral (13) menjadi

$$
\begin{aligned}
& E=8 \pi h c \int_{\infty}^{0}\left(\frac{k T}{h c}\right)^{5} y^{5} \frac{\left(-h c / k T y^{2}\right) d y}{e^{y}-1} \\
& =8 \pi h c\left(\frac{k T}{h c}\right)^{5}\left(\frac{h c}{k T}\right) \int_{\infty}^{0}-\frac{y^{3} d y}{e^{y}-1} \\
& =8 \pi h c\left(\frac{k T}{h c}\right)^{4} \int_{\infty}^{0} \frac{y^{3} d y}{e^{y}-1}
\end{aligned}
$$

Persamaan (14) merupakan kerapatan energi foton di dalam kotak. Hubungan antra kerapatan energi yang diradasi dengan energi foton dalam kotak adalah

$$
E_{\text {rad }}=\frac{c}{4} E=2 \pi h c^{2}\left(\frac{k T}{h c}\right)^{4} \int_{0}^{\infty} \frac{y^{3} d y}{e^{y}-1}=\left[2 \pi h c^{2}\left(\frac{k}{h c}\right)^{4} \int_{0}^{\infty} \frac{y^{3} d y}{e^{y}-1}\right] T^{4}
$$

Persamaan (15) sangat mirip dengan persamaan Stefan-Boltzman tentang energi yang diradiasi benda hitam, yaitu $E_{\text {rad }}=\sigma T^{4}$ dengan $\sigma$ konstanta Stefan-Boltzmann. Jadi, pada persamaan (16) kita dapat menyamakan

$$
\sigma=2 \pi h c^{2}\left(\frac{k}{h c}\right)^{4} \int_{0}^{\infty} \frac{y^{3} d y}{e^{y}-1}
$$

Dengan menggunakan instruksi Matematika sederhana kita dapatkan

$$
\int_{0}^{\infty} \frac{y^{3} d y}{e^{y}-1}=6,49394
$$

Selanjutnya, dengan memasukkan nilai konstanta-konstanta lain $k=1,38 \times 10^{-23} \mathrm{~J} / \mathrm{K}$, $h=6,625 \times 10^{-34} \mathrm{Js}$, dan $c=3 \times 10^{8} \mathrm{~m} / \mathrm{s}$ kita dapatkan nilai konstanta Stefan-Boltzmann

$$
\sigma=5,65 \times 10^{-8} \mathrm{~W} / \mathrm{m}^{2} \mathrm{~K}^{4}
$$




\section{Cosmic Microwave Background (CMB)}

Salah satu gejala penting sebagai hasil peristiwa Big Bang adalah keberadaan radiasi yang bersifat isotropik (sama ke segala arah) di alam semesta dalam panjang gelombang mikro. Gejala ini selanjutnya dikenal dengan cosmic microwave background $(\mathrm{CMB})$. Radiasi ini benar-benar isotropik. Penyimpangan dari sifat isotropic hanya sekitar seper seribu. Dua astronom muda, Arno Penzias and Robert Wilson yang pertama kali mengidentikasi gejala ini tahun 1965 dengan menggunakan antene horn yang dikalibrasi dengan sangat teliti. Dengan anggapan bahwa alam semesta berupa benda hitam sempurna dan setelah dilakukan pengukuran yang teliti intensitas radiasi gelombang mikro ini pada berbagai panjang gelombang yang mungkin, selanjutnya hasil pengukuran di-fit dengan persamaan radiasi benda hitam (Gbr.4) disimpulkan bahwa suhu rata-rata alam semesta sekarang adalah 2,725K.

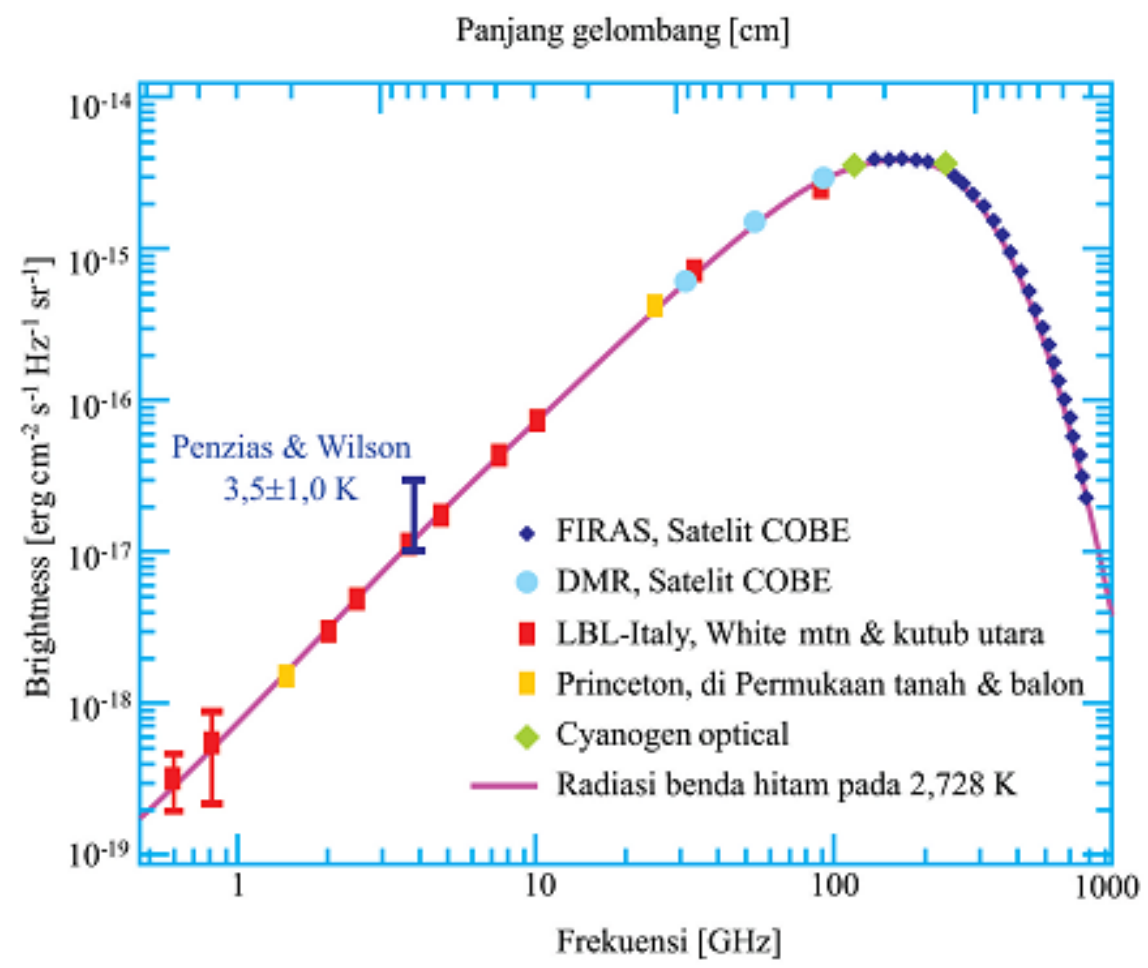

Gambar 4. Fitting data CMB dengan persamaan radiasi benda hitam (http://ircamera.as.arizona.edu/).

Ada sedikit variasi suhu pada arah yang berbeda seperti ditunjukkan dalam Gbr. 5 . Bagian berwarna merah sedikit lebih panas dan bagian berwarna biru sedikit lebih dingin dengan penyimpangan sekitar 0,0002 derajat. 


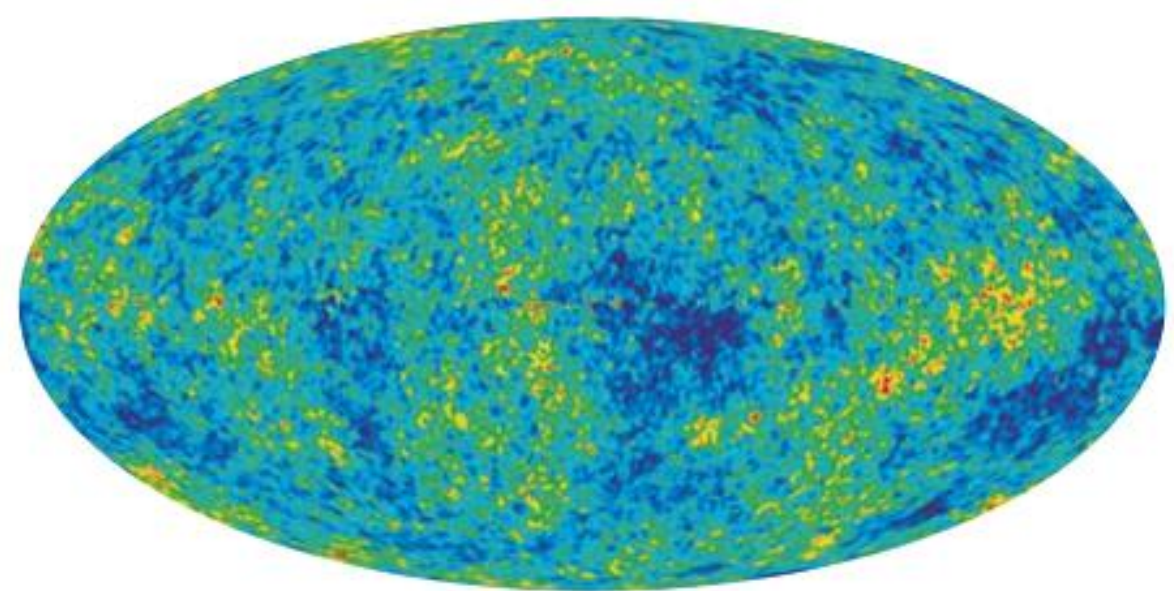

Gambar 5. Sedikit variasi suhu alam semesta berdasarkan posisi (http://www.oraberlin.de/soundbag/sbimages/rauschen.jpg). 


\section{KAPASITAS KALOR KRISTAL}

Dalam kristal atom-atom bervibrasi. Jika diselesaikan dengan mekanika kuantum maka energi vibrasi atom-atom dalam kristal terkuantisasi. Kuantisasi getaran atom tersebut disebut fonon. Energi fonon dengan bilangan kuantum $\mathrm{n}$ adalah $E_{n}=\left(n+\frac{1}{2}\right) \hbar \omega$. Karena jumlah fonon tidak konstan maka fungsi distribusi untuk fonon diperoleh dengan mengambil $\alpha=0$. Fungsi distribusi tersebut persis sama dengan fungsi distribusi foton.

Karena frekuensi fononnya merupakan fungsi bilangan gelombang $k$, maka secara umum energi total yang dimiliki fonon dalam kristal ditulis

$$
U=\sum \frac{\hbar \omega(\kappa)}{\exp [\hbar \omega(k) / k T]-1}
$$

Jika fonon memiliki sejumlah polarisasi dan polarisasi ke- $p$ memiliki frekuensi $\omega p(k)$; maka energi total fonon setelah memperhitungkan polarisasi tersebut adalah

$$
U=\sum_{p} \sum_{k} \frac{\hbar \omega_{p}(\kappa)}{\exp [\hbar \omega(\kappa) / k T]-1}
$$

Penjumlahan terhadap $\kappa$ dilakukan dengan asumsi bahwa $\kappa$ adalah integer. Tetapi jika $\kappa$ adalah variabel kontinu maka penjumlahan terhadap $\kappa$ dapat diganti dengan integral dengan melakukan transformasi sebagai berikut ini

$$
\sum_{\kappa} \rightarrow \int g_{p}(\kappa) d \kappa
$$

Tetapi, karena $\omega$ merupakan fungsi $\kappa$ maka kita dapat mengubah integral terhadap $\kappa$ menjadi integral terhadap $\omega$ dengan melakukan transformasi

$$
\sum_{\kappa} \rightarrow \int g_{p}(\kappa) d \kappa \rightarrow \int g_{p}(\omega) d \omega
$$

Akhirnya kita dapat menulis ulang persamaan (18) menjadi

$$
U=\sum_{p} \int g_{p}(\omega) \frac{\hbar \omega}{\exp \left[\hbar \omega / k_{B} T\right]-1} d \omega
$$

Dari definisi energi dalam dalam persamaan (21) maka kita dapat menentukan kapasitas panas yang didefinisikan sebagai berikut.

$$
\begin{aligned}
& C_{v}=\frac{d U}{d T} \\
& =\frac{d}{d T} \sum_{p} \int g_{p}(\omega) \frac{\hbar \omega}{\exp [\hbar \omega / k T]-1} d \omega \\
& =\sum_{p} \int g_{p}(\omega) \frac{d}{d T}\left\{\frac{1}{\exp [\hbar \omega / k T]-1}\right\} \hbar \omega d \omega
\end{aligned}
$$


Untuk menyederhanakan persamaan (22) mari kita lihat suku diferensial dalam persamaan tersebut. Untuk mempermudah kita misalkan $y=\hbar \omega / k T$. Dengan pemisalan tersebut maka

$$
\begin{aligned}
& \frac{d}{d T}=\frac{d}{d y} \frac{d y}{d T}=-\frac{\hbar \omega}{k T^{2}} \frac{d}{d y} \\
& \frac{d}{d T}\left\{\frac{1}{\exp [\hbar \omega / k T]-1}\right\}=\frac{d}{d T}\left\{\frac{1}{e^{y}-1}\right\}=-\frac{\hbar \omega}{k T^{2}} \frac{d}{d y}\left\{\frac{1}{e^{y}-1}\right\} \\
& =-\frac{\hbar \omega}{k T^{2}}\left\{\frac{-e^{y}}{\left(e^{y}-1\right)^{2}}\right\}=\frac{\hbar \omega}{k T^{2}} \frac{e^{y}}{\left(e^{y}-1\right)^{2}} \\
& =\frac{\hbar \omega}{k T^{2}} \frac{\exp [\hbar \omega / k T]}{(\exp [\hbar \omega / k T]-1)^{2}}
\end{aligned}
$$

Dengan demikian, kapasitas kalor dapat ditulis

$$
\begin{aligned}
& C_{v}=\sum_{p} \int g_{p}(\omega)\left\{\frac{\hbar \omega}{k T^{2}} \frac{\exp [\hbar \omega / k T]}{(\exp [\hbar \omega / k T]-1)^{2}}\right\} \hbar \omega d \omega \\
& =\frac{\hbar^{2}}{k T^{2}} \sum_{p} \int g_{p}(\omega) \frac{\exp [\hbar \omega / k T]}{(\exp [\hbar \omega / k T]-1)^{2}} \omega^{2} d \omega
\end{aligned}
$$

\subsection{Model Einsten}

Untuk mencari kapasitas kalor kristal, Einsten mengusulkan model bahwa semua phonon berosilasi dengan frekuensi karakteristik yang sama $\omega_{0}$. Dengan asumsi ini maka dapat ditulis

$$
g_{p}(\omega)=N \delta\left(\omega-\omega_{0}\right)
$$

Dimana $\delta\left(\omega-\omega_{0}\right)$ merupakan fungsi delta dirac. Dengan model ini kita dapatkan kapasitas kalor kristal untuk satu macam polarisasi saja sebesar

$$
\begin{aligned}
& C_{v}=\frac{\hbar^{2}}{k T^{2}} \int g(\omega) \frac{\exp [\hbar \omega / k T]}{(\exp [\hbar \omega / k T]-1)^{2}} \omega^{2} d \omega \\
& =\frac{\hbar}{k T^{2}} \int N \delta\left(\omega-\omega_{0}\right) \frac{\exp [\hbar \omega / k T]}{(\exp [\hbar \omega / k T]-1)^{2}} \omega^{2} d \omega \\
& =\frac{N \hbar^{2}}{k T^{2}} \frac{\exp \left[\hbar \omega_{0} / k T\right]}{\left(\exp \left[\hbar \omega_{0} / k T\right]-1\right)^{2}} \omega_{0}^{2}
\end{aligned}
$$

Untuk kristal 3 dimensi, terdapat tiga arah polarisasi fonon yang mungkin (arah sumbu $x, y$,dan $z$ ). Dengan menganggap bahwa e tiga polarisasi tersebut memberikan sumbangan energi yang sama besar maka kapasitas kalor total menjadi tiga kali dari yang tampak dalam persamaan (25), yaitu menjadi 


$$
C_{v}=\frac{3 N \hbar^{2}}{k T^{2}} \frac{\exp \left[\hbar \omega_{0} / k T\right]}{\left(\exp \left[\hbar \omega_{0} / k T\right]-1\right)^{2}} \omega_{0}^{2}
$$

Sekarang kita tinjau kasus-kasus khusus, yaitu ketika $T \rightarrow 0$ dan $T \rightarrow \infty$. Dalam kondisi $T \rightarrow 0$ maka exp [ $\left[\omega_{0} / k T\right]>>1$ sehingga $\exp \left[\hbar \omega_{0} / k T\right]-1 \approx \exp \left[\hbar \omega_{0} / k T\right]$ akibatnya

$$
\begin{aligned}
& C_{v} \approx \frac{3 N \hbar^{2}}{k T^{2}} \frac{\exp \left[\hbar \omega_{0} / k T\right]}{\left(\exp \left[\hbar \omega_{0} / k T\right]\right)^{2}} \omega_{0}^{2} \\
& =\frac{3 N \hbar^{2} \omega_{0}^{2}}{k T^{2}} e^{-\hbar \omega_{0} / k T}
\end{aligned}
$$

Perhatikan suku pembilang dan penyebut pada persamaan (10) $T \rightarrow 0$ maka suku penyebut $T^{2} \rightarrow 0$ dan suku pembilang $\exp \left[\hbar \omega_{0} / k T\right] \rightarrow 0$. Tetapi suku pembilang menuju nol jauh lebih cepat daripada suku penyebut. Dengan demikian $C_{v} \rightarrow 0$ jika $T \rightarrow 0$

Untuk kasus sebaliknya, yaitu $T \rightarrow \infty$ maka $\hbar \omega 0 / k T \rightarrow 0$ sehingga kita dapat mengaproksimasi

$$
\exp \left[\hbar \omega_{0} / k T\right] \approx 1+\frac{\hbar \omega_{0}}{k T}
$$

Dengan aproksimasi ini maka persamaan (27) dapat ditulis menjadi

$$
\begin{aligned}
& C_{v} \approx \frac{3 N \hbar^{2}}{k T^{2}} \frac{1+\hbar \omega_{0} / k T}{\left(1+\hbar \omega_{0} / k T-1\right)^{2}} \omega_{0}^{2} \\
& =\frac{3 N \hbar^{2}}{k T^{2}}\left(\frac{k T}{\hbar \omega_{0}}\right)^{2} \omega_{0}^{2} \\
& =3 N k=3\left(n N_{A}\right) k \\
& =3 n\left(N_{A} k\right)=3 n R
\end{aligned}
$$

Dengan $N_{A}$ bilangan Avogrado, $n$ jumlah mol dan $R=N_{A} k$ Konstanta gas umum. Hasil ini persis sama dengan teori klasik dari Dulong-Petit bahhwa kapasitas kalor per satuan mol semua padatan adalah konstan, yaitu $3 R$

Gambar 6. Adalah perbandingan hasil pengamatan kapasitas kalor intan(simbol) dan prediksi dengan model Einstein. Terdapat kesesuaian yang baik antara predikis model tersebut dengan pengamatan, khususnya nilai kapasitas kalor yang menuju nol jika suhu menuju nol dan nilai kapasitas kalor menuju konstanta Dulong-Petit pada suhu tinggi 


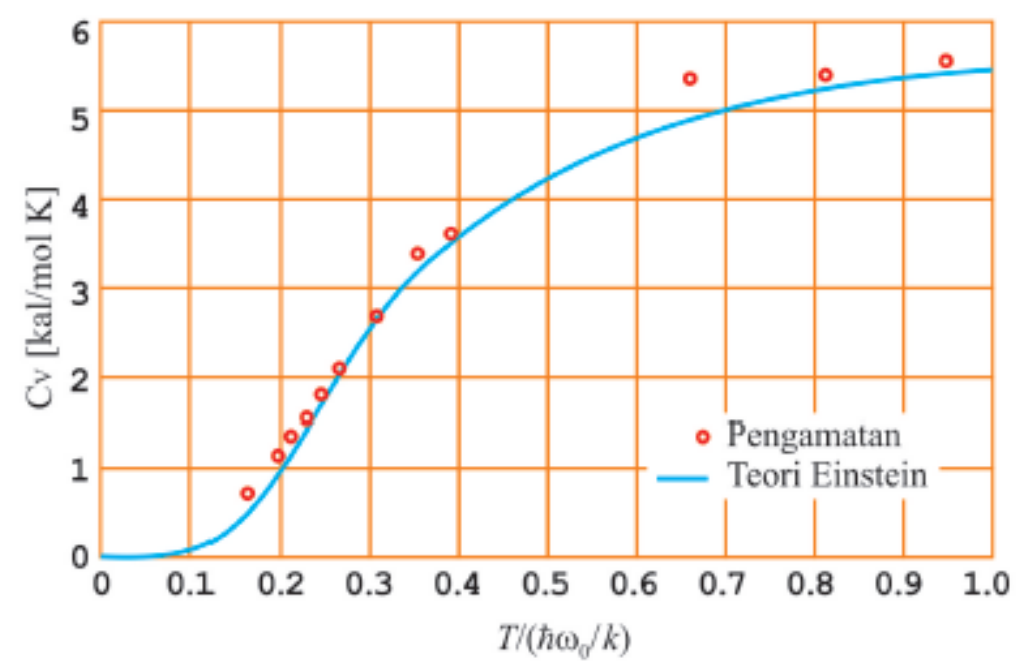

Gambar 6. Kapasitas panas intan yang diperoleh dari pengamatan (simbol) dan prediksi menggunakan model kapasitas panas einstein(kurva)

Model einstein dapat menjelaskan dengan baik kebergantungan kapasitas panas terhadap suhu, sesuai dengan pengamatan eksperimen bahwa pada suhu menuju nol apasitas panas menuju nol dan pada suhu sangat tinggi kapaistas panas menuju nilai yang diramalkan Dulong-Petit. Akan tetapi, masih ada sedikit penyimpangan antara data eksperimen dengan ramalan einstein. Pada suhu yang menuju nol, hasil eksperimen memperlihatkan bahwa kapasitas panas berubah sebagai fungsi kubik (panggkat tiga) dari suhu, bukan seperti pada persamaan (28). Oleh karena itu perlu penyempurnaan pada model Einstein untuk mendapat hasil yang persis sama dengan eksperimen.

\subsection{Model Debeye}

Salah satu masalah yang muncul dalam model einstein adalah asumsi bahwa semua fonon bervibrasi dengan frekuensi yang sama. Tidak ada justifikasi untuk asumsi ini. Asumsi ini digunakan semata-semata karena kemudahan mendapatkan solusi. Oelh karena itu hasil yang lebih tepat diharapkan muncul jika dianggap frekuensi fonon tidak seragam. Asumsi ini digunakan oleh Debeye untuk membangun teori kapasitas panas yang lebih teliti. Namun, sebelum masuk ke teori Debeye kita akan terlebih dahulu membahas kerapatan keadaan untuk kisi dalam usaha mencari ekspresi yang tepat untuk $g(\omega)$.

Frekuensi getaran kisi dalam kristal secara umum tidak konstan, tetapi bergantung pada bilangan gelombang. Persamaan yang menyatakan kebergantuungan frekuensi dengan bilangan gelombang dinamakan persamaan dispersi, $\omega=\omega(k)$. Dari persamaan dispersi tersebut dapat diturunkan persamaan kerapatan keadaan sebagai berikut:

$$
g(\omega)=\frac{V}{2 \pi^{2}} \frac{\kappa^{2}}{d \omega / d \kappa}
$$


Kebergantungan $\omega$ terhadap $\kappa$ kadang sangat kompleks. Sebagai contoh, untuk kristal satu dimensi, kita peroleh persamaan dispersi $\omega[(2 C / m)(1-\cos \kappa \alpha)]^{1 / 2}$, dengan $m$ massa atom, $C$ konstanta pegas getaran kisi, dan $\alpha$ jarak antar atom dalam kisi (periodistas). Namun, jika $\kappa$ sangat kecil, atau panjang gelombang yang besar $(\kappa=2 \pi / \lambda)$, kita dapatkan sebuah persamaan aproksimasi

$$
\omega=v_{g} \kappa
$$

Dengan $v_{g}$ disebut kecepatan gruo. Dalam membangun model kapasitas panas, Debye mengambil asumsi sebagai berikut.

1. Frekuensi getaran kisi memenuhi persamaan disepersi $\omega=v_{g} \kappa$

2. Ada sebuah frekuensi maksimum, $\omega_{m}$ yang boleh dimiliki fonon dalam kristal sehingga tidak ada fonon yang memiliki frekuensi di atas $\omega_{m}$

Dari persamaan dispersi (29) kita dapatkan bahwa untuk $\omega \leq \omega_{m}, k=\omega / v_{g}$ dan $d \omega / d k=v_{g}$ sehingga kerapatan keadaan pada persamaan (28) menjadi $g(\omega)=$ $v \omega^{2} / 2 \pi v g^{3}$. Akhirnya jika digabung dengan asumsi kedua tentang adanya frekuensi maksimum getaran fonon diperoleh ungkapan umum untuk kerapatan keadaan sebagai berikut.

$$
g(\omega)= \begin{cases}\frac{V}{2 \pi v^{3}} \omega^{2}, & \omega \leq \omega_{m} \\ 0 & \omega>\omega_{m}\end{cases}
$$

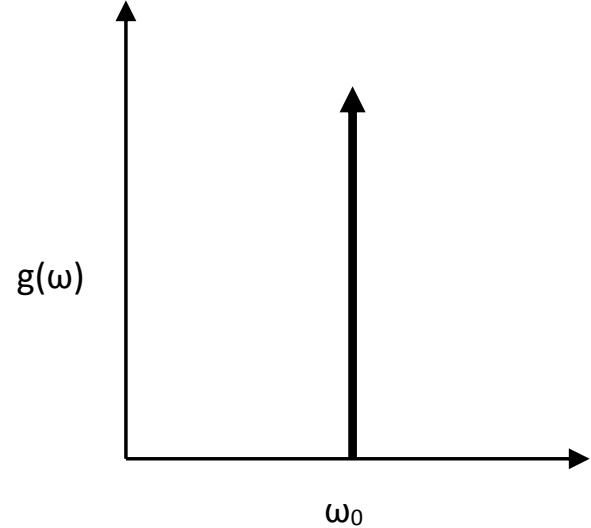

Model Einstein

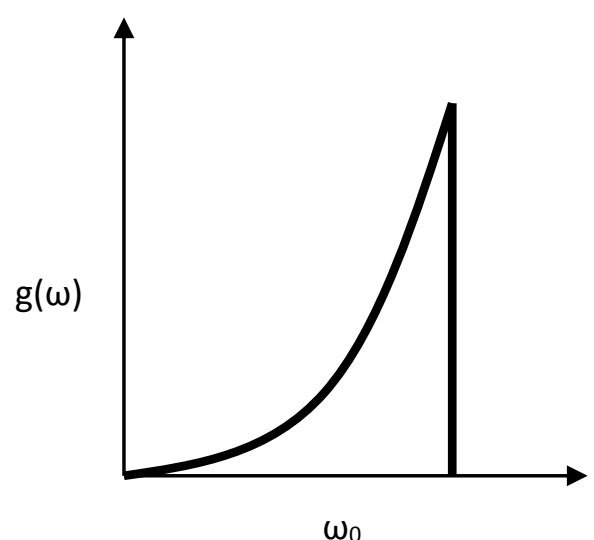

Model Debye

Gambar. 7 Kurva kerapatan keadaan sebagai fungsi pada model Einstein dan Debye

Perbedaan kurva kerapatan keadaan sebagai fungsi pada model Einstein dan Debye diperlihatkan pada gambar 7. Berapa nilai $\omega_{m}$ pada model Debye? Untuk menentukan $\omega_{m}$ kita kembali kepada definisi bahwa $g(\omega)$ adalah jumlah keadaan per satuan frekuensi. Karena frekuensi maksimum fonon adalah $\omega_{m}$ maka integral $g(\omega)$ dari frekuensi 0 sampai $\omega_{m}$ memberikan jumlah total keadaan yang dimiliki fonon, dan itu sama dengan jumlah atom,N. Jadi 


$$
\begin{aligned}
& \int_{0}^{\omega_{m}} g(\omega) d \omega=N \\
& \int_{0}^{\omega_{m}} \frac{V}{2 \pi v_{g}^{3}} \omega^{2} d \omega=N \\
& \frac{V}{2 \pi v_{g}^{3}} \int_{0}^{\omega_{0}} \omega^{2} d \omega=N \\
& \frac{V}{2 \pi v_{g}^{3}} \frac{\omega^{3}{ }_{m}}{3}=N
\end{aligned}
$$

Yang memberikan ungkapan untuk frekuensi maksimum

$$
\omega_{m}^{3}=\frac{6 \pi v_{g}^{3} N}{V}
$$

Untuk kemudahan mari kita didefiniskan suhu Debye, $\Theta_{\mathrm{D}}$, berdasarkan hubungan berikut ini

$$
k_{B} \Theta_{D}=\hbar \omega_{m}
$$

Dengan definisi di atas kita dapatkan

$$
\Theta_{D}=\frac{\hbar v_{g}}{k_{B}}\left(\frac{6 \pi^{2} N}{V}\right)^{1 / 3}
$$

Kita Asumsikan bahwa kapasitas kalor kisi yang dihasilkan oleh tiap polarisasi fonon sama besarnya. Karena terdapat tiga polarisasi getaran yang kemungkinan maka penjumlahan terhadap indeks $p$ dalam persamaan (24) menghasilkan tiga kali nilai per polarisasi. Akibatnya, tanda sumasi dapat diganti dengan nilai tiga dan kita peroleh kapasitas panas yang disumbangkan oleh semua polarisasi menjadi

$$
\begin{aligned}
& C v=3 \frac{\hbar^{2}}{k T^{2}} \int_{0}^{\infty} g(\omega) \frac{e^{\hbar \omega / k T}}{\left(e^{\hbar \omega / k T}-1\right)^{2}} \\
& =\frac{3 \hbar^{2}}{k T^{2}} \int_{0}^{\omega_{m}} g(\omega) \frac{e^{\hbar \omega / k T}}{\left(e^{\hbar \omega / k T}-1\right)^{2}} \omega^{2} d \omega+\frac{3 \hbar^{2}}{k T^{2}} \int_{\omega_{m}}^{\infty} g(\omega) \frac{e^{\hbar \omega / k T}}{\left(e^{\hbar \omega / k T}-1\right)^{2}} \omega^{2} d \omega \\
& =\frac{3 \hbar^{2}}{k T^{2}} \int_{0}^{\omega_{m}}\left(\frac{V}{2 \pi v_{g}^{3}} \omega^{2}\right) \frac{e^{\hbar \omega / k T}}{\left(e^{\hbar \omega / k T}-1\right)^{2}} \omega^{2} d \omega+\frac{\hbar^{2}}{k T^{2}} \int_{\omega_{m}}^{\infty}(0) \frac{e^{\hbar \omega / k T}}{\left(e^{\hbar \omega / k T}-1\right)^{2}} \omega^{2} d \omega \\
& =\frac{3 \hbar^{2} V}{2 \pi v_{g}^{3} k T^{2}} \int_{0}^{\omega_{m}} \frac{e^{\hbar \omega / k T}}{\left(e^{\hbar \omega / k T}-1\right)^{2}} \omega^{4} d \omega
\end{aligned}
$$

Untuk menyelesaikan integral pada persamaan (35) kita misalkan $x=\hbar \omega / k T$. Dengan permisalan tersebut maka 


$$
\begin{aligned}
& \omega=\frac{k T}{\hbar} x \\
& d \omega=\frac{k T}{\hbar} d x
\end{aligned}
$$

Selanjutnya, syarat batas untuk x ditentukan sebagai berikut. Jika $\omega=0$ maka $x=0$ dan jika $\omega=\omega_{m}$ maka $x=\hbar \omega_{m} / k T=k \Theta_{D} / k T=\Theta_{D} / T$. Dengan demikian, bentuk integral untuk kapasitas panas menjadi

$$
\begin{aligned}
& C v=\frac{3 \hbar^{2} V}{2 \pi v_{g}^{3} k T^{2}} \int_{0}^{\Theta_{D} / T} \frac{e^{x}}{\left(e^{x}-1\right)^{2}}\left(\frac{k T}{\hbar} x\right)^{4} \frac{k T}{\hbar} d x \\
& =\frac{3 V k^{4} T^{3}}{2 \pi v_{g}^{3} \hbar^{3}} \int_{0}^{\Theta_{D} / T} \frac{x^{4} e^{x}}{\left(e^{x}-1\right)^{2}} d x
\end{aligned}
$$

Berdasarkan definisi $\Theta_{\mathrm{D}}$ pada persmaan (34) maka dapat ditulis $\Theta_{D}^{3}=6 \pi^{2} \hbar v g^{3} / k^{3} V$ atau $V k^{4} T^{3} / 2 \pi v_{g}^{3}=3 N k\left(T / \Theta_{D}\right)^{3}$. Substistusi hubungan ini ke persamaan (36) diperoleh ungkapan kapasitas kalor dalam bentuk yang lebih sederhana sebagai berikut.

$$
C_{v}=9 N k\left(\frac{T}{\Theta_{D}}\right)^{3} \int_{0}^{\Theta_{D} / T} \frac{x^{4} e^{x}}{\left(e^{x}-1\right)^{2}} d x
$$

Selajutnya kita tinjau beberapa kasus khusus yaitu ketika $T \rightarrow 0$ dan $T \rightarrow \infty$ jika $T \rightarrow 0$ maka $\Theta_{D} / T \rightarrow \infty$ sehingga

$$
C_{v} \approx 9 N k\left(\frac{T}{\Theta_{D}}\right)^{3} \int_{0}^{\Theta_{D} / T} \frac{x^{4} e^{x}}{\left(e^{x}-1\right)^{2}} d x
$$

Bagian Integral tidak bergantung lagi pada $\mathrm{T}$ dan hasil integral adalah sebuah bilangan. Dengan program matematika maka akan diperoleh hasi integral pada persamaan (38) adalah.

$$
\int_{0}^{\infty} \frac{x^{4} e^{x}}{\left(e^{x}-1\right)^{2}} d x=\frac{\pi^{2}}{15}
$$

Dengan demikian, untuk $T \rightarrow 0$ diperoleh

$$
\begin{aligned}
& C_{v} \approx \frac{9 \pi^{2} N k}{15}\left(\frac{T}{\Theta_{D}}\right)^{3} \\
& =A T^{2}
\end{aligned}
$$

Dengan

$$
A \approx \frac{9 \pi^{2} N k}{15 \Theta_{D}^{3}}
$$

Persamaan (41) sangat sesuai dengan hasil eksperimen. 
Sebaliknya, untuk $T \rightarrow \infty$ maka penyebut pada persamaan (37) dapat diaproksimasikan $e^{x}-1 \approx x$ dan pada pembilang dapat diaproksimasikan $e^{x} \approx 1$ sehingga

$$
\begin{aligned}
& C_{v} \approx 9 N k\left(\frac{T}{\Theta_{D}}\right)^{3} \int_{0}^{\Theta_{D} / T} \frac{x^{4}}{(x)^{2}} d x \\
& =9 N k\left(\frac{T}{\Theta_{D}}\right)^{3} \int_{0}^{\Theta_{D} / T} x^{2} d x=9 N k\left(\frac{T}{\Theta_{D}}\right)^{3} \frac{1}{3}\left(\frac{\Theta_{D}}{T}\right)^{3} \\
& =3 N k
\end{aligned}
$$

Yang juga persis sama dengan ramalan Dulong-Petit

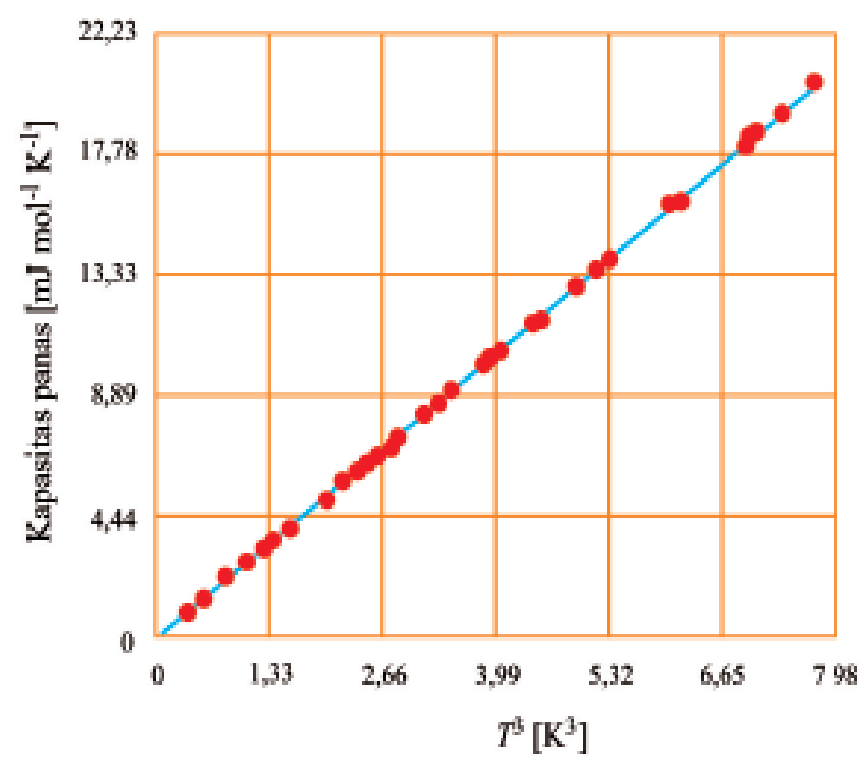

Gambar 8. Hasil pengukuran kapasitas panas argon padat (titik-titik) beserta kurva yang diperoleh menggunkan model Debye.

Pada Gambar 8.tampak bahwa ramalan Debye tentang, kebergantungan kapasitas kalor pada pangkat tiga suhu sangat sesuai dengan hasil pengamatan. Teori Debye dan Einstein hanya berbeda pada suhu rendah. Pada suhu agak tinggi, kedua teori tersebut memprediksikan hasil yang sangat mirip dan pada suhu yang sangat tinggi kedua teori ini memberikan prediksi yang persis sama dengan hukuum Dulong Petit.

\section{Kondensasi Bose Einstein}

Kita kembali melihat bentuk fungsi distribusi BE. Jumlah sistem yang menempati keadaan dengan energi En pada suhu T adalah

$$
N\left(E_{n}, T\right)=\frac{1}{\exp \left(E_{n}-\mu\right) / k T-1}
$$

Tampak jelas dari ungkapan di atas bahwa pada suhu yang sangat rendah sistem-sistem akan terkonsentrasi di keadaan-keadaan dengan energi sangat rendah. Jika $T \rightarrow 0$ maka 
jumlah sistem yang menempati tingkat energi paling rendah, tingkat energi kedua, ketiga, dan seterusnya makin dominan. Jumlah sistem yang menempati keadaankeadaan dengan nilai energi tinggi makin dapat diabaikan. Hampir semua sistem akan berada pada tingkat energi terendah jika suhu didinginkan hingga dalam orde $10^{-14} \mathrm{~K}$. Tampak jelas dari ungkapan di atas bahwa pada suhu yang sangat rendah.

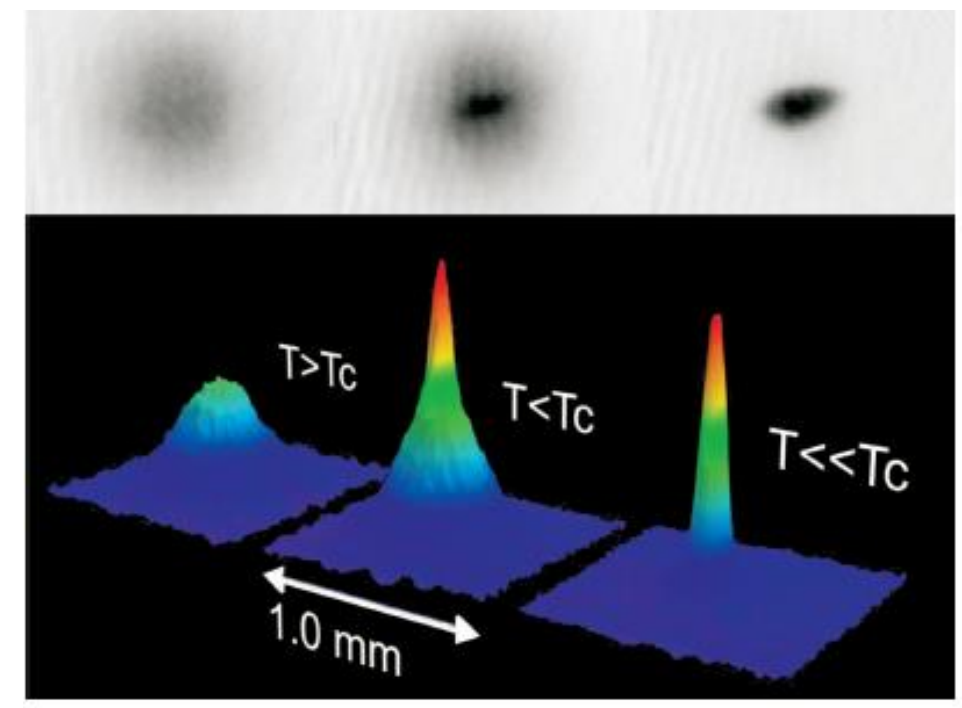

Gambar 9. Salah satu hasil pengukuran mempbuktikan kondensasi Bose- Einstein

Namun, ada fenomena yang menarik di sini. Ternyata untuk boson, keadaan dengan energi terendah dapat ditempati oleh sistem dalam jumlah yang sangat besar pada suhu yang jauh lebih tinggi dari $10^{-14} \mathrm{~K}$. Dengan kata lain, boson tidak perlu menunggu suhu serendah $10^{-14} \mathrm{~K}$. Untuk mendapatkan sistem dalam jumlah yang sangat besar pada tingkat energi terendah. Pada beberapa material, seperti helium, jumlah sistem yang sangat besar pada tingkat energi terendah dapat diamati pada suhu setinggi $3 \mathrm{~K}$. Jadi terjadi semacam kondensai boson pada suhu yang jauh lebih tinggi dari prediksi klasik. Fenomena ini dikenal dengan kondensasi Bose-Einstein. Bagaimana menjelaskan fenomena kondensasi ini?

\subsection{Kebergantungan Potensial Kimia Pada Suhu}

Mari kita tengok kembali fungsi distribusi Bose-Einstein. Untuk mudahnya kita gunakan skala energi sedemikian sehingga tingkat terendah memiliki energi $E o=0$. Populasi keadaan dengan tingkat energi sembarang diberikan oleh persamaan (43). Jumlah populasi yang menempati tingkat energi terendah $(E o=0)$ adalah

$$
n(0, T)=\frac{1}{\exp (0-\mu) / k T-1}=\frac{1}{\exp (-\mu / k T)-1}
$$


Pada suhu $T \rightarrow 0$ hampir semua sistem menempati keadaan dengan energi terendah. Dengan demikian, jumlah populasi pada tingkat ini memiliki orde kira-kira sama dengan jumlah total sistem, atau

$$
N=\lim _{T \rightarrow 0} n(o, T)=\lim _{T \rightarrow 0} \frac{1}{\exp (-\mu / k T)-1}
$$

Karena nilai $\mathrm{N}$ sangat besar (dalam orde $10^{23}$ ) maka ketika $T \rightarrow 0$ penyebut Pada $\frac{1}{[\exp (-\mu / k T)-1]}$ harus menuju nol. Sebab, jika tidak maka $\frac{1}{[\exp (-\mu / k T)-1]}$ tidak akan menghasilkan nilai $\mathrm{N}$ yang sangat besar. Nilai $[\exp (-\mu / k T)]$ akan menuju nol hanya jika $\exp (-\mu / k T)$ menuju satu. Fungsi eksponensial $\exp (x)$ mendekati 1 jika $x \rightarrow 0$. Jadi kita simpulkan bahwa pada $T \rightarrow 0$ akan berlaku $\mu / k T \rightarrow 0$. Dan jika $\mu / k T \rightarrow 0$ maka kita dapat melakukan aproksimasi.

$$
\exp (-\mu / k T) \approx 1-\frac{\mu}{k T}
$$

Jadi kita dapatkan aproksimasi berikut ini

$$
N==\lim _{T \rightarrow 0} \frac{1}{\exp (-\mu / k T)-1} \approx \frac{1}{\exp (-\mu / k T)-1}=-\frac{k T}{\mu}
$$

Atau

$$
\mu \approx-\frac{k T}{N}
$$

Hubungan pada persamaan (47) menyatakan bahwa pada suhu $T \rightarrow 0$ maka $\mu$ berharga negatif dan merupakan fungsi linier dari suhu. Sebagai ilustrasi, pada $\mathrm{T}=1 \mathrm{~K}$ dan $N=$ $10^{22}$ maka $\mu \approx-1,4 \times 10^{-38} \mathrm{erg}$. Ini adalah nilai yang sangat kecil. Bahkan nilai ini jauh lebih kecil daripada jarak antar dua tingkat energi terdekat dalam assembli atom helium di dalam kubus dengan sisi $1 \mathrm{~cm}$. Kebergantungan $\mu$ pada suhu itulah yang menyebabkan peristiwa kondensasi Bose-Einstein. Agar lebih memahami fenomena kondensasi Bose-Einstein, mari kita perhatikan sistem-sistem yang berada dalam kubus dengan sisi $L$. Tingkat- tingkat energi yang dimiliki assembli memenuhi

$$
E\left(n_{x} n_{y} n_{z}\right)=\frac{\hbar^{2}}{2 M}\left(\frac{\pi}{L}\right)^{2}\left(n_{x}^{2}+n_{y}^{2}+n_{z}^{2}\right)
$$

Tingkat energi terendah bersesuaian dengan $n x=n y=n z=1$, yaitu

$$
E(111)=\frac{\hbar^{2}}{2 M}\left(\frac{\pi}{L}\right)^{2}(1+1+1)
$$

Salah satu tingkat energi berikutnya bersesuaian dengan $n_{x}=n_{y}=1$ dan $n_{z}=2$, yaitu

$$
E(112)=\frac{\hbar^{2}}{2 M}\left(\frac{\pi}{L}\right)^{2}(1+1+4)
$$


Selisih tingkat energi terendah dan tingkat energi berikutnya adalah

$$
\Delta E=E(112)-E(111)=3 \times \frac{\hbar^{2}}{2 M}\left(\frac{\pi}{L}\right)^{2}
$$

Jika assembli terebut adalah atom helium $M=\left(6,6 \times 10^{-24} \mathrm{~g}\right)$ dalam kubus dengan sisi 1 $\mathrm{cm}$ maka $\Delta E \cong 2,48 \times 10^{-38} \mathrm{erg}$. Apabila kita prediksi populasi sistem pada tingkat energi eksitasi pertama dan tingkat energi terendah dengan menggunakan statistik Maxwell-Boltzmann adalah

$$
\frac{n_{1}}{n_{0}}=\exp (-\Delta E / k T)
$$

Pada suhu $T=1 \mathrm{mK}$ maka

$$
\frac{n_{1}}{n_{0}}=\exp \left(-\frac{2,48 \times 10^{-30} \mathrm{erg}}{k \times 10^{-3} \mathrm{~K}}\right) \cong 1
$$

Hasil di atas berarti bahwa pada suhu $1 \mathrm{mK}$, tingkat energi terendah dan eksitasi pertama memiliki populasi yang hampir sama. Namun, dengan statistik Bose-Einstein kita mendapatkan hasil yang sangat berbeda. Dengan asumsi $N=10^{20}$ dan suhu $T=1$ mK maka kita peroleh

$$
\mu=-\frac{k T}{N}=-\frac{k x 10^{-3}}{10^{22}}=1,4 \times 10^{-41} \operatorname{erg}
$$

Jumlah populasi yang menempati tingkat energi eksitasi pertama (tepat diatas tingkat energi paling rendah) adalah

$$
n\left(E_{1}, T\right)=\frac{1}{\exp \left(E_{1}-\mu\right) / k T-1}
$$

Karena $E o=0$ maka $E_{1}=\Delta E$ Lebih lanjut, mengingat $|\mu|<<\Delta E$ maka $E_{1}-\mu \approx E_{1}=\Delta E$. Dengan demikian

$$
n\left(E_{1}, T\right)=\frac{1}{\exp \left(E_{1}-\mu\right) / k T-1}=\frac{1}{\exp \left(2,48 \times 10^{30}\right) /\left(k x 10^{-3}\right)-1} \approx 5 \times 10^{10}
$$

Dengan demikian, fraksi sistem pada tingkat energi eksitasi pertama adalah

$$
\frac{n\left(E_{1}\right)}{N} \approx \frac{5 \times 10^{10}}{10^{22}} \approx 5 \times 10^{-12}
$$

tampak bahwa fraksi sistem pada tingkat energi eksitasi pertama amat kecil. Ini berarti bahwa sebagian besar sistem berada pada tingkat energi terendah. 


\subsection{Suhu Kondensasi Einsteinn}

Sudah kita pelajari pada bab-bab sebelumnya bahwa kerapatan keadaan kuantum untuk sistem dengan spin nol dapat ditulis dengan

$$
g(E)=\frac{V}{4 \pi^{2}}\left(\frac{2 M}{\hbar^{2}}\right)^{3 / 2} E^{1 / 2}
$$

Pada suhu $\mathrm{T} \rightarrow 0$ sebagian sistem menempati tingkat energi terendah dengan jumlah yang sangat signifikan. Jumlah total sistem dalam assembli dapat ditulis.

$$
\begin{aligned}
& n=\sum N\left(E_{n}\right)=n_{0}(T)+\sum_{n \neq 0} n\left(E_{n}\right) \\
& =n_{0}(T)+\int_{0}^{\infty} g(E) f(E, T) d E=n_{0}(T)+n_{e}(T)
\end{aligned}
$$

dengan $n_{0}(T)$ adalah jumlah sistem pada tingkat energi terendah dan $n_{e}(T)=\int_{0}^{\infty} g(E) f(E, T) d E$ dan jumlah total sistem yang menempati tingkat-tingkat energi lainnya. Dengan mengambil skala energi $E o=0$ maka jumlah sistem pada tingkat energi terendah dapat ditulis

$$
n_{0}(T)=\frac{1}{\exp (-\mu / k T)-1}
$$

Jumlah sistem yang menempati semua tingkat energi lainnya adalah

$$
\begin{aligned}
n_{e}(T) & =\frac{V}{4 \pi^{2}}\left(\frac{2 M}{\hbar^{2}}\right)^{3 / 2} \int_{0}^{\infty} \frac{E^{1 / 2}}{\exp (E-\mu) / k T-1} d E \\
& =\frac{V}{4 \pi^{2}}\left(\frac{2 M}{\hbar^{2}}\right)^{3 / 2} \int_{0}^{\infty} \frac{E^{1 / 2}}{\exp (-\mu / k T) \exp (E / k T)-1} d E
\end{aligned}
$$

Karena $n_{o}(T) \rightarrow N$ pada suhu yang mendekati nol maka haruslah $\exp (-\mu=k T) \rightarrow 1$. Dengan sifat ini maka persamaan (51) dapat disederhanakan menjadi

$$
n_{\varepsilon}(T) \approx \frac{V}{4 \pi^{2}}\left(\frac{2 M}{\hbar^{2}}\right)^{3 / 2} \int_{0}^{\infty} \frac{E^{1 / 2}}{\exp (E / k T)-1} d E
$$

Untuk menyelesaikan (52) kita lakukan substitusi $E / k T=x$. Dengan demikian $E^{1 / 2}=(k T)^{1 / 2} x^{1 / 2}, \exp (E / k T)=\exp (x)$, dan $d E=(k T) d x$. Selanjutnya integral pada persamaan (52) dapat ditulis

$$
\int_{0}^{\infty} \frac{E^{1 / 2}}{\exp (E / k T)-1} d E=(k T)^{3 / 2} \int_{0}^{\infty} \frac{x^{1 / 2}}{\exp (x)-1} d x=1,306 \pi^{2}(k T)^{3 / 2}
$$


Akhirnya kita dapatkan

$$
\begin{aligned}
n_{e}(T) & \approx \frac{V}{4 \pi^{2}}\left(\frac{2 M}{\hbar^{2}}\right)^{3 / 2} \times 1,306 \pi^{2}(k T)^{3 / 2} \\
& =2,612 n_{Q} V
\end{aligned}
$$

Dengan

$$
n_{Q}=\left(\frac{M k T}{2 \pi \hbar^{2}}\right)^{3 / 2} \text { dinamakan konsentrasi kuantum. }
$$

Kita definisikan suhu kondensasi Bose-Einstein, $T_{E}$ sebagai suhu ketika jumlah sistem pada keadaan terkesitasi persis sama dengan jumlah total sistem. Jadi, pada $T=T_{E}$, terpenuhi $n_{e}\left(T_{E}\right)=N$. Dengan menggunakan persamaan (53) kita dapatkan bahwa pada suhu kondensasi Bose-Einstein terpenuhi.

$$
N=\frac{V}{4 \pi^{2}}\left(\frac{2 M}{\hbar^{2}}\right)^{3 / 2} \times 1,306 \pi^{2}\left(k T_{E}\right)^{3 / 2}
$$

yang memberikan

$$
T_{E}=\frac{2 \pi \hbar^{2}}{M k}\left(\frac{N}{2,612 V}\right)^{2 / 3}
$$

Pada sembarang suhu yang mendekati nol derajat, fraksi jumlah sistem pada keadaan tereksitasi adalah

$$
\frac{n_{e}(T)}{N}=\left(\frac{T}{T_{E}}\right)^{3 / 2}
$$

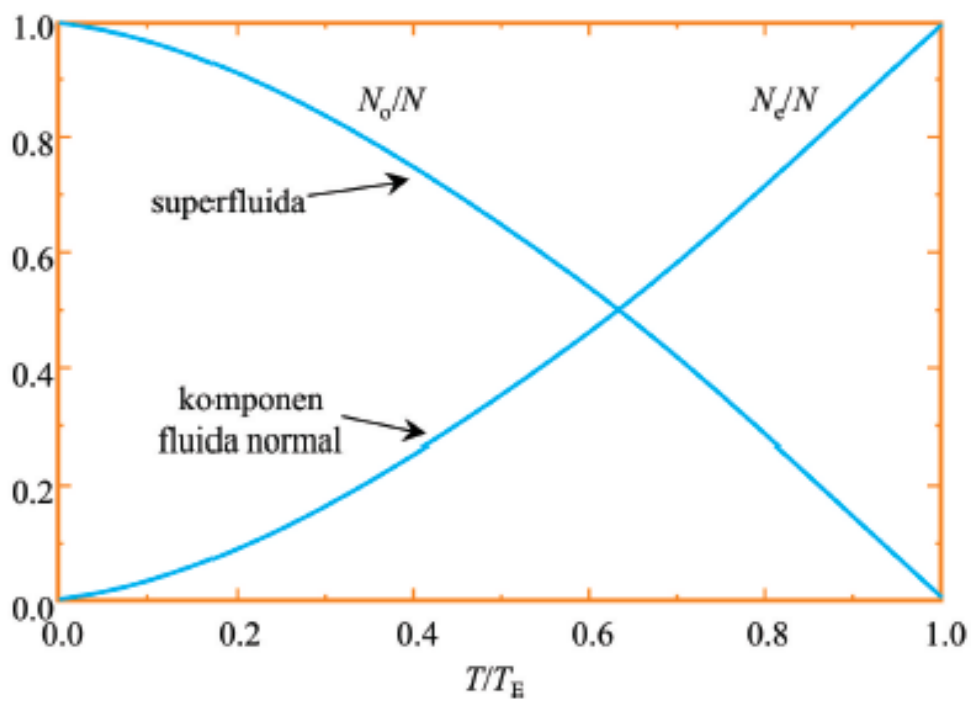

Gambar 10. Fraksi superuida (sistem yang menempati keadaan dasar) dan fuida normal (sistem yang menempati keadaan eksitasi) dalam assembli boson sebagai fungsi suhu ketika suhu berada di bawah suhu kondensasi Bose-Einstein 
Berarti pula bahwa fraksi jumlah sistem pada keadaan paling rendah adalah

$$
\frac{n_{o}(T)}{N}=1-\frac{n_{\varepsilon}(T)}{N}=1-\left(\frac{T}{T_{E}}\right)^{3 / 2}
$$

Gambar 10. adalah kurva fraksi $N e / N$ dan $N c / N$ yang diberikan oleh persamaan (55) dan (56). Adalah fraksi boson yang menempati keadaan energi terendah $N_{0}$ dan boson yang menempati keadaan tereksitasi $N e$ sebagai fungsi suhu. Boson yang terkondensasi membentuk fase yang dinamakan superfluida dan boson yang menempati keaadaan tereksitasi dinamakan fluida normal. Superfluida hanya dijumpai ketika suhu $T$ lebih rendah dar $T_{E}$. 


\section{DAFTAR PUSTAKA}

Abdullah, Mikrajuddin. 2009. Fisika Statistik untuk Mahasiswa MIPA. Bandung : Institut Teknologi Bandung

Beiser. Arthur. 1999. Konsep Fisika Modern Edisi Keempat. Jakarta : PT. Penerbit erlangga Mahameru

Viridi, Sparisoma, dkk. 2010. Catatan Kuliah Fisika Statistik. E-Book Download pada 12 Desember 2014 
